\title{
$\overline{\underline{ }}$ \\ Figures, Maps, and Tables
}

Figures

Figure 1.1 Dome of the Rock in the Haram al-Sharif enclosure 4I

Figure 1.2 The "Wall" or Separation or Barrier, which divides Jerusalem from the West Bank 43

Figure 1.3 Schoolgirl waits for her friends inside the Haram al-Sharif 50

Figure 1.4 Israeli soldiers in soft berets, indicating a low threat level, patrol the Damascus Gate in the Old City, Jerusalem 53

Figure 2.1 View of the Mezquita-Cathedral showing the Gothic basilica extruding from the roof of the former mosque 78

Figure 2.2 Islamic doorway to the former minaret, now the clock tower of the Mezquita-Cathedral 79

Figure 3.1 View of northern Banaras and the Ganges River from the roof of Alamgari Mosque, with mosque courtyard in the foreground $\mathrm{I} 3 \mathrm{O}$

Figure 3.2 View looking south from the roof of the Alamgari Mosque toward the Vishweshwur Temple and showing the ghats that line the River Ganges I3I

Figure 3.3 Stones prepared and waiting for the building of the Ram Temple (Ram Janmabhumi) in Ayodhya to commence I4I

Figure 3.4 Rapid Action Force watchtower beside the Gyan Vapi Mosque I45 
Figure 4.1 Monks' Assembly Hall in the Potala Palace, Lhasa I63

Figure 4.2 View northward from the Potala Palace, showing the new suburbs of Lhasa $\quad$ I77

Figure 4.3 Chinese paramilitary police patrol the kora around the Jokhang Temple, Lhasa 200

Figure 5.1 The Ten Thousand Buddhas Pagoda at the Kek Lok Si Temple, George Town 2I3

Figure 5.2 Leaflet for walking tour of the Street of Harmony, George Town, emphasizing the common values of the different religious practices $23 \mathrm{I}$

\section{Maps}

Map 1.1 Jerusalem metropolitan area 37

Map 1.2 Jerusalem Old City and environs 40

Map 2.1 Cordoba metropolitan area 67

Map 2.2 Cordoba Old City and environs 88

Map 3.1 Banaras city center and insert showing Gyan Vapi Mosque and Vishweshwur Temple ios

Map 4.1 Lhasa metropolitan area, with inset of the region I56

Map 4.2 Lhasa Old City and environs $\quad$ I75

Map 5.1 George Town and Penang Island 2I6

Map 5.2 George Town city center and UNESCO Heritage Zone 229

\section{Tables}

Table 3.1 Population of India by Religion (Hindu and Muslim) by Percentage, I99I-20II II3

Table 3.2 Population (Hindu and Muslim) by Percentage for Banaras District, Uttar Pradesh, and India, 20I I II5

Table 3.3 Population of Banaras City by Religion, 20I I II6 